\title{
MICROSCOPIC STUDY ON THE SHAPE OF PINEAL CALCIFICATION OF BANGLADESHI CADAVERS
}

\author{
AFROZ H ${ }^{1}$, NURUNNABI ASM ${ }^{2}$, ARA ${ }^{3}$, RAHMAN M ${ }^{4}$, PERVEN HA ${ }^{5}$
}

\begin{abstract}
:
Context: The degree of calcification increases from younger to older in human pineal gland and the morphology of pineal calcifications change with advancing age as well. The aim of the present study was to describe the microscopic features of the pineal calcifications and find out age related changes in a Bangladeshi population.
\end{abstract}

Methods: A descriptive type of study was done in the Department of Anatomy, Dhaka Medical College, from July 2009 to June 2010, based on the collection of 60 human pineal glands from whole human brains of unclaimed dead bodies that were under postmortem examination in the Department of Forensic Medicine, Dhaka Medical College, Dhaka. After collection of the pineal gland, those were divided into group A (15-45 years), group B (31-40 years), group C (41-50 years) and group $D$ (>50 years). All the histological slides from different groups were observed under the light compound microscope and their shapes were noted down.

Results: In group A, 53.33\% were found to be round, $40 \%$ oval and $6.67 \%$ of irregular shape. In group B, there were $45.46 \%$ round, $40.90 \%$ oval and $13.64 \%$ of irregular shape. In group C, there were $75 \%$ of irregular shape, $21.47 \%$ mulberry shaped and $3.53 \%$ oval. In group D, there were $80.65 \%$ mulberry shaped and $19.35 \%$ of irregular shaped.

Conclusion: Age related changes were found in morphological features of pineal calcification. In young adults, the shape of the pineal calcification remains round or oval. With increasing age, it becomes irregular and mulberry shaped.

Key words: Pineal gland, pineal calcification, cadaver

J Dhaka Med Coll. 2013; 22(2) : 151-155.

\section{Introduction:}

The pineal gland (or the epiphysis cerebri) is a small, piriform, reddish grey organ, occupying a depression in between the superior colliculi ${ }^{1}$. Pineal calcifications or 'pineal acervuli' (also called 'brain sand', 'pineal sand', 'corpora arenacea' etc.) were first described by Giovanni Batista Morgagni in the $18^{\text {th }}$ century ${ }^{2}$. Schiller, in 1918, first described the pineal calcification on radiograph of the skull ${ }^{2}$. In addition to the cells, the human pineal gland is characterized by the presence of the calcified concretions, called 'corpora aranacea' or brain sand ${ }^{3}$. These are basophilic extracellular bodies ${ }^{4}$. These concretions appear to be derived from precipitation of calcium phosphates and carbonates on carrier proteins that are released into the cytoplasm when the pineal secretions are exocytosed. The concretions are recognizable in childhood and increase in number with age ${ }^{3}$. The calcifications are to be found likely in two locations, intrapineal in the pineal parenchyma and extrapineal in the pineal capsule ${ }^{5}$.

The pineal calcification is a special interest to the radiologists, as because its displacement indicates intracranial space occupying lesion and pineal enlargement indicates pineal tumour 6,7 . The degree of calcification increases from younger to older age groups. The morphology of pineal calcification also changes with advancing age ${ }^{2}$. Moreover, by acquiring the exact knowledge of histological features of

1. Dr. Halima Afroz, Assistant Professor, Department of Anatomy, Green Life Medical College, Dhaka.

2. Dr. Abu Sadat Mohammad Nurunnabi, Lecturer, Department of Anatomy, Dhaka Medical College, Dhaka.

3. Prof. Shamim Ara, Professor and Head, Department of Anatomy, Dhaka Medical College, Dhaka.

4. Dr. Mushfika Rahman, Assistant Professor, Department of Anatomy, Dr. Sirajul Islam Medical College, Dhaka.

5. Dr. Hosna Ara Perven, Assistant Professor, Department of Anatomy, The Medical College for Women \& Hospital, Uttara, Dhaka.

Correspondence: Dr. Halima Afroz, Assistant Professor, Department of Anatomy, Green Life Medical College, Dhaka. 
the pineal calcifications, it is possible to diagnose the pathological condition such as hyperplasia, tumour etc. ${ }^{7}$. The present study is a modest effort to describe the microscopic features of the pineal calcifications and to find out whether there is any age related change.

\section{Methods:}

A descriptive type of study was designed and done in the Department of Anatomy, Dhaka Medical College, Dhaka, from July 2009 to June 2010 , to see the microscopic features of the calcifications of the human pineal gland. The present study was performed on 60 human pineal glands collected from whole human brains of unclaimed dead bodies that were under postmortem examination in the Department of Forensic Medicine, Dhaka Medical College, Dhaka, from August 2009 to June 2010. After the legal formalities, whole of the human brain was collected within 24-36 hours of death. During collection of the samples, appropriate age, sex and the cause of death were noted from the morgue's record book. The samples were brought to the Department of Anatomy, Dhaka Medical College, Dhaka. The samples were tagged immediately bearing code numbers for subsequent identification. Soon after collection, each sample was gently washed with tap water on a dissection tray. Blood and blood clots were removed as far as possible.

\section{Preservation of brains:}

After collection of whole brain, $100 \mathrm{ml}$ of $40 \%$ formaldehyde solution was injected by using a $50 \mathrm{cc}$ syringe into the brain through the surfaces (superolateral and inferior surfaces). Then it was preserved in $40 \%$ formaldehyde solution for 15 days. After 15 days the pineal glands were collected from the preserved brains and the pineal gland fixed in $10 \%$ formol saline solution.

Procedure of collection of pineal gland from preserved brain:

After fixation of the whole of the human brain, the pineal gland was collected by the following steps:

At first, the fingers were placed in the medial part of the horizontal fissure of the left half of the cerebellum and it was separated. Thus the total of the superior and parts of the middle and inferior cerebellar peduncles were exposed. The thin layer of the white matter near the posterior border of the cerebellum was picked up by using a blunt forceps. Exposing the superior cerebellar peduncles, the pineal gland was identified in between the depression of the superior colliculi and observed that it was attached to the dorsal surface of the brain, at the junction of the midbrain and the diencephalon and inferior to the splenium of the corpus callosum ${ }^{8}$. An incision of about $1-2 \mathrm{~cm}$ was given through the splenium of the corpus callosum to approach the pineal region. The pineal gland was taken out from the diencephalon with a careful semilunar cut $^{2}$. The pineal gland was cleared up from other tissues. Then, it was preserved in a small plastic jar containing $10 \%$ formol saline solution for further histological procedures.

\section{Common Exclusion Criteria:}

a) Decomposed body,

b) Any history of injury to the head,

c) Any suspected pathology of the pineal gland seen by naked eyes, and

d) If the whole of the pineal gland is not available during dissection.

\section{Grouping of the sample:}

For convenience, all the samples were categorized in 4 groups i.e. group A (15-30 years), group B (31-40 years), group C (41-50 years) and group D (>50 years) (according to Golan et al. $)^{9}$ (Table-I).

Preparation of the slide:

Tissue blocks were fixed in $10 \%$ formol saline in a plastic container. The tissues were washed in running tap water, dehydration was done with ascending grades of alcohol, cleared with xylene, infiltrated and embedded in paraffin. Paraffin blocks were cut at $5 \mathrm{~mm}$ thickness and were stained with routine Harris' Haematoxylin and Eosin (H \& E) stain. Only the best prepared slides were taken for for examination. The light compound microscope which was used for the microscopic measurement was OLYMPUS CHB, made in Tokyo, Japan. 
Determination of the shape of the pineal calcification:

After detecting the area of calcification of the pineal gland under low magnification (x 10 objective $\mathrm{x} 10$ eyepiece) of the light microscope, its shape was observed (according to Antiæ et al.) $)^{2}$.

\section{Ethical clearance:}

The present study was approved by the Ethical Review Committee of Dhaka Medical College, Dhaka.

\section{Results:}

Different shapes of the pineal calcification were found depending on age (Fig.1). In the present study, different shapes of the pineal calcification were identified under the microscope. In group A, 53.33\% were found to be round, $40 \%$ oval and $6.67 \%$ of irregular shape. In group B, there were $45.46 \%$ round, $40.90 \%$ oval and $13.64 \%$ of irregular shape. In group $\mathrm{C}$, there were $75 \%$ of irregular shape, $21.47 \%$ mulberry shaped and $3.53 \%$ oval. In group D, there were $80.65 \%$ mulberry shaped and $19.35 \%$ of irregular shaped. Moreover, as a whole, $57-14 \%$ calcification were found in group A, $71.43 \%$ in group B and C and $83.33 \%$ in group D (Table-IIa \& IIb, Fig.2).

Table-I

Grouping of the sample of the present study $(n=60)$

\begin{tabular}{llcc}
\hline Group & Age limit & \multicolumn{2}{c}{ Number of samples } \\
& & Male & Female \\
\hline A & 15-30 years & 09 & 09 \\
B & 31-40 years & 17 & 08 \\
C & 41-50 years & 08 & 03 \\
D & $>50$ years & 06 & 00 \\
\hline
\end{tabular}

Table-IIa

Presence of the pineal calcification in different age group

\begin{tabular}{lccc}
\hline Group & No. of slides & $\begin{array}{c}\text { No. of slides where } \\
\text { calcification present }\end{array}$ & $\begin{array}{c}\text { No. of slides where } \\
\text { calcification absent }\end{array}$ \\
\hline A & 7 & 4 & 3 \\
B & 7 & 5 & 2 \\
C & 7 & 5 & 2 \\
D & 6 & 5 & 1 \\
\hline
\end{tabular}

Table-IIb

Shape of the pineal calcification in different age group

\begin{tabular}{|c|c|c|c|c|c|}
\hline \multirow{2}{*}{\multicolumn{2}{|c|}{$\begin{array}{lc}\text { Group } & \text { No. of } \\
\text { calcifications }\end{array}$}} & \multicolumn{4}{|c|}{ Shape of the calcification } \\
\hline & & Round & Oval & Irregular & Mulberry \\
\hline A & 15 & $8(53.33 \%)$ & $(40 \%)$ & $1 \quad(6.67 \%)$ & 0 \\
\hline \multirow[t]{2}{*}{ B } & 22 & 10 & 9 & 3 & 0 \\
\hline & & $(45.46 \%)$ & (40.90\%) & $(13.64 \%)$ & \\
\hline $\mathrm{C}$ & 28 & 0 & $1 \quad(3.57 \%)$ & $21 \quad(75 \%)$ & $6(21.43 \%)$ \\
\hline \multirow[t]{2}{*}{$\mathrm{D}$} & 31 & 0 & 0 & 6 & 25 \\
\hline & & & & $(19.35 \%)$ & $(80.65 \%)$ \\
\hline
\end{tabular}




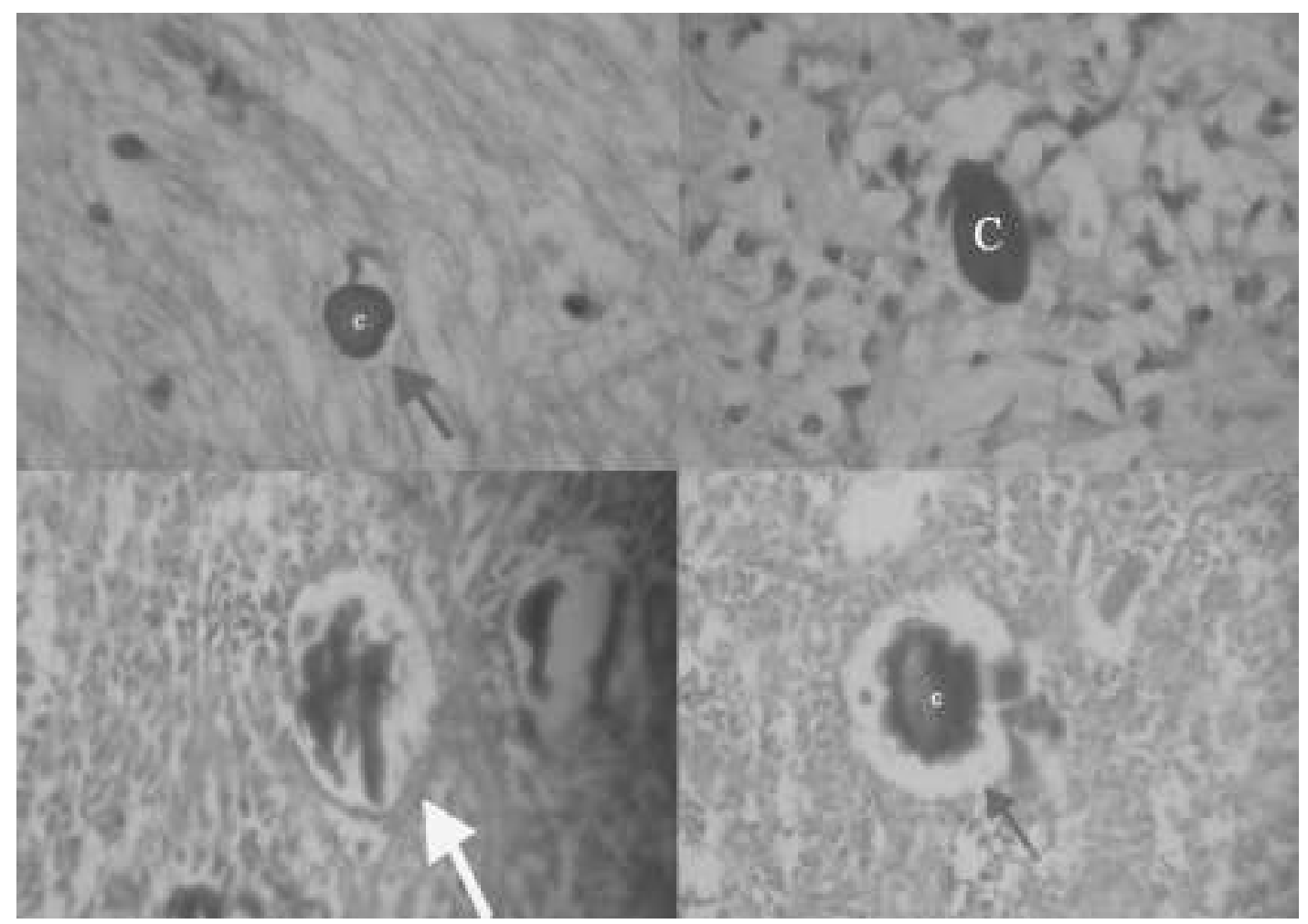

Fig.-1. Photomicrographs of the pineal gland showing round shaped calcification (blue arrow) from group A (15-30 years); oval shaped calcification (green arrow) from group B (31-40 years); irregular shaped calcification (yellow arrow) from group C (41-50 years); and mulberry shaped calcification (green arrow) from group $D$ (>50 years); seen under the light microscope $(\times 10$ objective $\times 10$ eyepiece) (H \& E stain).

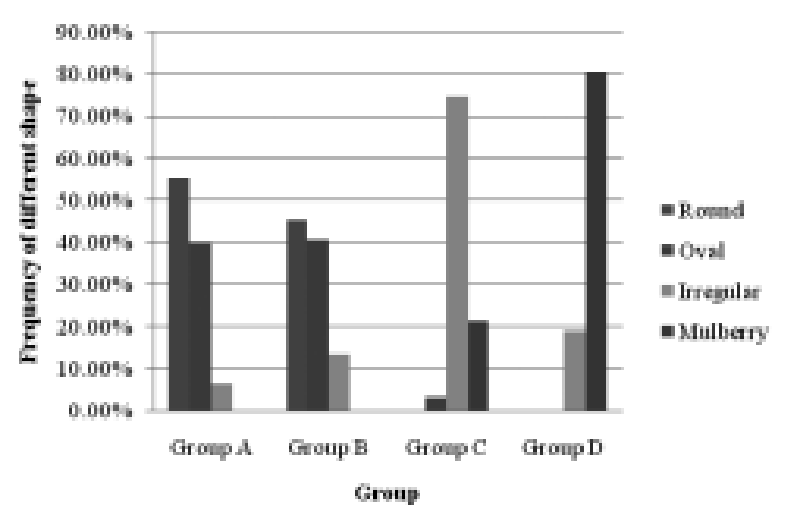

Group A (15-30 years), Group B (31-40 years) Group C (41-50 years), Group D (>50 years)

Fig. 2. Shape of the pineal calcification in different age group.

\section{Discussion:}

The degree of calcification invariably increases from younger to older age groups and occasionally, 'corpora aranacea' are absent in some adults ${ }^{10}$. The present study also reported absence of clacilfication in some adult specimens. Nevertheless, in the present study, the presence of calcified concretions need not reflect a pathological state as these pineal glands were collected from road traffic accident dead bodies, whose health status was unknown and who probably were of normal health. Kelly, Wood and Enders ${ }^{11}$ stated that the pineal calcifications are mulberry shaped. They did not mention anything about age related changes. According to Vigh et al. ${ }^{12}$, the amount of calcarous deposits does not seem to increase significantly as age advances. However, the pattern of deposit differs and they reported the presence of calcium alongside the cell membranes and that meningeal "corpora aranacea' are in the form of concentric lamellae and intrapineal as globular. According to $\mathrm{Izadi}^{7}$, the pineal calcification is typically ' $\mathrm{C}$ ' shaped. Koshy and Vettivel ${ }^{5}$ stated that globular shape of calcification is found in younger age group and concentric lamellated type occurs in older 
age group. According to Antiæ et al. ${ }^{2}$, acervuli of the $1^{\text {st }}$ age group (20-44 years) are small with regular, round or oval shape, of the $2^{\text {nd }}$ group (45-69 years) are larger and more irregular in shape i.e. more wrinkled and more uneven at their surface and of the $3^{\text {rd }}$ group $(70$ years and more), they are much more wrinkled and uneven than ever, and finally leading to a mulberry like acervuli. Cytoplasmic microacervuli are localized ultrastructurally in pineal gland from age of 2 days to 86 years and barely present or frequently absent in the oldest subjects; their involvement in the secretory activity rather than in gland atrophy suggests a close relationship between cytoplasmic microacervuli and intermediate microfilaments and a possible role of the cytoskeleton in the formation of corpora $\operatorname{aranacea}^{12,13}$. The shapes of the pineal calcification observed in the present study are more or less similar to that of Antiæ et $\mathrm{al}^{2}$, Koshy and Vettivel ${ }^{5}$, Izadi ${ }^{7}$, Kelly, Wood and Enders ${ }^{11}$ and Vigh et al. ${ }^{12}$.

\section{Conclusion:}

Age related changes were found in morphological features of pineal calcification. In young adults, the shape of the pineal calcification remains round or oval. With increasing age, it becomes irregular and mulberry shaped. To the best of our knowledge, this is the first ever experiment done in our country on pineal gland. Further studies with larger samples and advanced stereological technique are recommended.

\section{References:}

1. Crossman AR. ed. Neuroanatomy. In: Stranding S, Ellis H, Heally JC, Johnson D, Williams A, Collins P, et al. eds. Gray's anatomy: the anatomical basis of clinical practice. $39^{\text {th }}$ ed. Edinburgh: Elsevier Churchill Livingstone; 2005: p.324.
2. Antiæ S, Javanoviæ I, Stefanoviæ N, Pavloviæ S, Ranèiæ G, Ugrenoviæ S. Morphology and histochemical characteristics human pineal gland acervuli during the aging. Facta Universitatis: Med Biol 2004; 11(2): 63-8.

3. Ross MH, Pawlina W. Histology: a text and atlas with correlated cell and molecular biology. $5^{\text {th }}$ ed. Baltimore: Lippincott Williams \& Wilkins; 2006. p.698-700.

4. Young B, Lowe JS, Stevens A, Heath JW. eds. Wheather's functional histology: a text and colour atlas. $5^{\text {th }}$ ed. Edinburgh: Churchill Livingstone; 2006: p.344.

5. Koshy S, Vettivel SK. Varying appearances of calcification in human pineal gland: a light microscopic study. J Anat Soc India 2001; 50(1): $17-8$.

6. Zimmarman RA, Bilaniuk LT. Age-related incidence of pineal calcification detected by computed tomography. Radiology 1982; 142: 65962.

7. Izadi S. Intracranial calcification. Shiraz eMed J 2003; 4: 1-9.

8. Romanes GJ. ed. Cunningham's manual of practical anatomy. Vol.3. 15 $5^{\text {th }}$ ed. New York: Oxford University Press; 2000: p.244-5.

9. Golan J, Torres K, Staœkiewicz GJ, Opielak G, Maciejewski R. Morphometric parameters of the human pineal gland in relation to age, body weight and height. Folia Morphol 2002; 61(2): 111-3.

10. Krabbe KH. Development of the pineal organ and a rudimentary parietal eye in some birds. J Comp Neurol 1955; 103(1): 139-49.

11. Kelly DE, Wood RL, Enders AC. Bailey's textbook of microscopic anatomy. $18^{\text {th }}$ ed. Baltimore: Williams \& Wilkins; 1984: p.816-20.

12. Vígh B, Szél A, Debreceni K, Fejér Z, Manzano e Silva MJ, Vígh-Teichmann I. Comparative histology of pineal calcification. Histol Histopathol 1998; 13(3): 851-70.

13. Galliani I, Frank F, Gobbi P, Giangaspero F, Falcieri E. Histochemical and ultrastructural study of human pineal gland in the course of aging. $\mathrm{J}$ Submicros Cytol Pathol 1989; 21(3): 571-8. 